\title{
PEMBERDAYAAN MASYARAKAT DAN PENGEMBANGAN KAPASITAS DALAM PENANGGULANGAN KEMISKINAN MELALUI PNPM MANDIRI PERKOTAAN
}

\author{
Bambang Sugeng Dwiyanto (bsugengd@yahoo.co.id) \\ Fakultas Ekonomi, Universitas Proklamasi 45 Yogyakarta \\ Jemadi (jemadi08@yahoo.com) \\ Fakultas Ekonomi, Universitas Proklamasi 45 Yogyakarta
}

\begin{abstract}
Community empowerment is an attempt to make people become empowered through learning efforts so that they are able to manage and be responsible for development programs in the community. Learning is implemented in a series of community development. The purpose of this research was to evaluate the process of community empowerment in PNPM Urban activities in terms of aspects Sastrodirjan village community development, with the goal of research is to assess the implementation of community development, assessing public attitudes and perspectives on community empowerment and assess the degree of empowerment. The approach in this research is deductive method of qualitative analysis and quantitative descriptive. Results reveal that the capacity of community development activities in the village Sastrodirjan has been implemented in accordance with the principles of empowerment and have managed to change the level of public awareness and increase understanding of the role of development in their communities. The findings obtained are changes in public awareness of the respondents did not relate to age, level of education and its role in PNPM, but having a relationship with sex, where the role and involvement of women is still low and not enough to support optimal development at the community level.
\end{abstract}

Keywords: Empowerment, capacity, community PNPM Urban, development at the community level.

\section{PENDAHULUAN.}

Pembangunan pada hakikatnya merupakan suatu rangkaian upaya yang dilakukan secara terus menerus untuk mencapai suatu tingkat kehidupan masyarakat yang sejahtera lahir dan batin, untuk itu peran serta masyarakat dalam pembangunan sangat diperlukan karena merekalah objek sekaligus subjek pembangunan, sehingga berkembanglah model 
pembangunan partisipatif. Pembangunan partisipatif merupakan pendekatan pembangunan yang sesuai dengan hakikat otonomi daerah yang meletakkan landasan pembangunan yang tumbuh berkembang dari masyarakat, diselenggarakan secara sadar dan mandiri oleh masyarakat dan hasilnya dinikmati oleh seluruh masyarakat (Sumaryadi, 2005: 87). Melalui program-program pembangunan partisipatif tersebut diharapkan semua elemen masyarakat dapat secara bersama-sama berpartisipasi dengan cara mencurahkan pemikiran dan sumber daya yang dimiliki guna memenuhi kebutuhannya sendiri.

Pembangunan partisipatif erat kaitannya dengan pemberdayaan masyarakat, dimana pada pembangunan partisipatif diperlukan upaya dan langkah-langkah untuk mempersiapkan masyarakat guna memperkuat kelembagaan masyarakat agar mereka mampu mewujudkan kemajuan, kemandirian, dan kesejahteraan dalam suasana keadilan yang berkelanjutan untuk meningkatkan harkat dan martabatnya serta mampu melepaskan diri dari perangkap kemiskinan dan keterbelakangan. Upaya tersebut merupakan salah satu wujud nyata dari pemberdayaan masyarakat (Sumaryadi, 2005: 111).

Pemberdayaan masyarakat pada dasarnya merupakan proses untuk membuat masyarakat menjadi berdaya. Untuk menggerakkan kembali kemandirian masyarakat dalam pembangunan di komunitasnya, maka diperlukan dorongan-dorongan atau gagasan awal untuk menyadarkan kembali peran dan posisinya dalam kerangka untuk membangun masyarakat madani. Proses penyadaran masyarakat tersebut dilakukan melalui konsep-konsep pengembangan kapasitas.

Pengembangan kapasitas masyarakat pada hakikatnya merupakan usaha meningkatkan kemampuan masyarakat itu sendiri. Apabila masyarakat sebagai pihak yang paling berkepentingan belum memahami secara betul makna dari pengembangan kapasitas itu sendiri dan tidak memberikan tanggapan secara positif terhadap upaya-upaya pengembangan kapasitas yang dilaksanakan maka bisa dipastikan upaya tersebut tidak akan berdaya guna dan berhasil sesuai tujuan yang ingin dicapai. Wilson (2006) menjelaskan empat tahapan dalam pemberdayaan masyarakat, yaitu tahap penyadaran, tahap pemahaman, tahap pemanfaatan, dan tahap pembiasaan.

Tahap pembiasaan adalah tahapan paling akhir dalam proses pemberdayaan, dimana masyarakat telah terbiasa untuk terlibat secara aktif dalam pembangunan di lingkungannya.

Untuk pengembangan kapasitas masyarakat ini, diluncurkanlah Program Nasional Pember-dayaan Masyarakat Mandiri Perkotaan (PNPM Mandiri Perkotaan). PNPM Mandiri Perkotaan ini merupakan kelanjutan dari Program Penang-gulangan Kemiskinan Perkotaan (P2KP) yang telah dilaksanakan sejak tahun 1999 sebagai suatu upaya pemerintah 
untuk membangun kemandirian masyarakat dan pemerintah daerah dalam menanggulangi kemiskinan secara berkelanjutan. Program ini berupaya menyiapkan landasan kemandirian masyarakat berupa lembaga kepemimpinan masyarakat yang representatif, mengakar dan kondusif bagi perkembangan modal sosial (social capital) masyarakat di masa mendatang serta menyiapkan program masyarakat jangka menengah dalam penanggulangan kemiskinan yang menjadi pengikat dalam kemitraan masyarakat dengan pemerintah daerah dan kelompok peduli setempat (Departemen Pekerjaan Umum, 2008).

Salah satu agenda penting di tingkat masyarakat terkait pelaksanaan PNPM Mandiri Perkotaan ini adalah kegiatan pengembangan kapasitas indvidu masyarakat, yang pada tataran pelaksanaan di masyarakat meliputi proses sosialisasi, pelatihan dan pelaksanaan siklus pemberdayaan. Dalam implementasinya ketiga proses tersebut harus berjalan terus dan berkesinambungan karena yang diharapkan dari pemberdayaan adalah pembiasaan masyarakat dalam pembangunan yang partisipatif .

Dalam kondisi yang ideal proses pengembangan kapasitas masyarakat harus dijalankan dengan menyesuaikan kemampuan dan karakteristik masyarakat setempat, sehingga bisa jadi proses tersebut memerlukan waktu dan pendekatan yang berbeda-beda antar satu komunitas dengan komunitas lainnya. Hal ini disebabkan karena latar belakang pemikiran yang beragam yang dipengaruhi oleh status sosial, jenis kelamin, usia, pekerjaan dan tingkat pendidikan. Oleh karena itu derajat keberdayaan masyarakat akan sangat bervariasi meskipun proses pengembangan kapasitas yang ada dilakukan dengan pendekatan yang sama dan dalam waktu yang bersamaan.

Penelitian ini dilakukan di Desa Sastrodirjan Kecamatan Wonopringgo Kabupaten Pekalongan. Desa Sastrodirjan adalah salah satu desa yang menerima program pemberdayaan masyarakat yaitu PNPM Mandiri Perkotaan yang pelaksanaannya telah dimulai pada tahun 2007 dan masih berjalan sampai sekarang ini. Desa Sastrodirjan merupakan salah satu lokasi yang dianggap cukup berhasil dalam pelaksanaan PNPM Mandiri Perkotaan karena memiliki progress yang cukup baik dilihat dari pelaksanaan kegiatan telah sesuai agenda-agenda yang telah direncanakan baik dalam kegiatan pemberdayaan masyarakatnya maupun dalam kegiatan pembangunan fisik lingkungannya.

Artikel yang didasarkan pada hasil penelitian ini bertujuan untuk mengelaborasi secara mendalam dan komprehensif implementasi serta tingkat keberhasilan pemberdayaan masyarakat dan pengembangan kapasitas dalam rangka penanggulangan kemiskinan melalui PNPM Mandiri Perkotaan di Desa Sastrodirjan Kec. Wonopringgo Kabupaten Pekalongan. 


\section{TINJAUAN PUSTAKA.}

\section{Pemberdayaan Masyarakat.}

\section{a. Pembangunan di Era Desentralisasi.}

Tujuan utama dari pembangunan adalah meningkatkan taraf hidup dan menciptakan masyarakat sejahtera secara fisik, mental maupun sosial, namun pendekatan yang digunakan dalam pembangunan harus senantiasa mengutamakan proses daripada hasil. Pendekatan proses lebih memungkinkan pelaksanaan pembangunan yang memanusiakan manusia. Dalam pandangan ini pelibatan masyarakat dalam pembangunan lebih mengarah kepada bentuk partisipasi, bukan dalam bentuk mobilisasi. Partisipasi masyarakat dalam perumusan program membuat masyarakat tidak semata-mata berkedudukan sebagai konsumen program, tetapi juga sebagai produsen karena telah terlibat dalam proses pembuatan dan perumusannya, sehingga masyarakat merasa ikut memiliki program dan tanggung-jawab bagi keberhasilannya serta memiliki motivasi yang lebih bagi partisipasi pada tahap-tahap berikutnya (Soetomo, 2006).

Partisipasi masyarakat dalam pembangunan bisa didapatkan ketika masyarakat tersebut telah mampu membawa dirinya untuk ikut terlibat dalam pembangunan, sehingga konsep pembangunan partisipatif harus juga dibarengi dengan pemberdayaan masyarakat. Untuk menuju kepada usaha pembangunan partisipatif yang sebenarnya, masyarakat yang mampu untuk mengembangkan komunitasnya menuju ke arah kemajuan, maka pemberdayaan masyarakat menjadi satu hal yang harus dilaksanakan.

\section{b. Siklus dan Proses Pemberdayaan Masyarakat}

Pemberdayaan menurut arti secara bahasa adalah proses, cara, perbuatan membuat berdaya, yaitu kemampuan untuk melakukan sesuatu atau kemampuan bertindak yang berupa akal, ikhtiar atau upaya (Depdiknas, 2003). Pemberdayaan masyarakat sering dimaknai sebagai upaya untuk memberikan kekuasaan agar suara mereka didengar guna memberikan kontribusi kepada perencanaan dan keputusan yang mempengaruhi komunitasnya (Foy, 1994). Memberdayakan orang lain pada hakikatnya merupakan perubahan budaya, sehingga pemberdayaan tidak akan jalan jika tidak dilakukan perubahan seluruh budaya organisasi secara mendasar. Perubahan budaya sangat diperlukan untuk mampu mendukung upaya sikap dan praktik bagi pemberdayaan yang lebih efektif (Sumaryadi, 2005: 105).

Berdasarkan beberapa pengertian di atas, secara umum pemberdayaan masyarakat dapat diartikan sebagai upaya untuk memulihkan atau meningkatkan kemampuan suatu komunitas untuk mampu berbuat 
sesuai dengan harkat dan martabat mereka dalam melaksanakan hakhak dan tanggungjawabnya selaku anggota masyarakat. Rubin dalam Sumaryadi (2005: 94-96) mengemukakan 5 prinsip dasar dari konsep pemberdayaan masyarakat sebagai berikut:

- Pemberdayaan masyarakat memerlukan break-even dalam setiap kegiatan yang dikelolanya, meskipun orientasinya berbeda dari organisasi bisnis, di mana dalam pemberdayaan masyarakat keuntungan yang diperoleh didistribusikan kembali dalam bentuk program atau kegiatan pembangunan lainnya.

- Pemberdayaan masyarakat selalu melibatkan partisipasi masyarakat baik dalam perencanaan maupun pelaksanaan yang dilakukan.

- Dalam melaksanakan program pember-dayaan masyarakat, kegiatan pelatihan merupakan unsur yang tidak bisa dipisahkan dari usaha pembangunan fisik.

- Dalam implementasinya, usaha pember-dayaan harus dapat memaksimalkan sumber daya, khususnya dalam hal pembiayaan baik yang berasal dari pemerintah, swasta maupun sumber-sumber lainnya '

- Kegiatan pemberdayaan masyarakat harus dapat berfungsi sebagai penghubung antara kepentingan pemerintah yang bersifat makro dengan kepentingan masyarakat yang bersifat mikro

Pemahaman mengenai konsep pemberdayaan tidak bisa dilepaskan dari pemahaman mengenai siklus pemberdayaan itu sendiri, karena pada hakikatnya pemberdayaan adalah sebuah usaha berkesinambungan untuk menempatkan masyarakat menjadi lebih proaktif dalam menentukan arah kemajuan dalam komunitasnya sendiri. Artinya program pemberdayaan tidak bisa hanya dilakukan dalam satu siklus saja dan berhenti pada suatu tahapan tertentu, akan tetapi harus terus berkesinambungan dan kualitasnya terus meningkat dari satu tahapan ke tahapan berikutnya.

Menurut Wilson (1996) terdapat7 tahapan dalam siklus pemberdayaan masyarakat, yaitu

\begin{tabular}{|l|l|}
\hline $\begin{array}{l}\text { Tahap } \\
\text { pertama }\end{array}$ & $\begin{array}{l}\text { keinginan dari masyarakat sendiri untuk berubah } \\
\text { menjadi lebih baik. }\end{array}$ \\
\hline Tahap kedua & $\begin{array}{l}\text { mampu melepaskan halangan-halangan atau faktor- } \\
\text { faktor yang bersifat resistensi terhadap kemajuan } \\
\text { dalam dirinya dan komunitasnya. }\end{array}$ \\
\hline Tahap ketiga & $\begin{array}{l}\text { sudah menerima kebebasan tambahan dan merasa } \\
\text { memiliki tanggungjawab dalam mengem-bangkan } \\
\text { dirinya dan komunitasnya. }\end{array}$ \\
\hline
\end{tabular}




\begin{tabular}{|l|l|}
\hline $\begin{array}{l}\text { Tahap } \\
\text { keempat }\end{array}$ & $\begin{array}{l}\text { upaya untuk mengembangkan peran dan batas } \\
\text { tanggungjawab yang lebih luas, juga terkait dengan } \\
\text { minat dan motivasi untuk melakukan pekerjaan } \\
\text { dengan lebih baik. }\end{array}$ \\
\hline Tahap kelima & $\begin{array}{l}\text { mulai adanya hasil-hasil nyata peningkatan rasa } \\
\text { memiliki yang lebih besar dan menghasilkan keluaran } \\
\text { kinerja yang lebih baik. }\end{array}$ \\
\hline $\begin{array}{l}\text { Tahap } \\
\text { keenam }\end{array}$ & $\begin{array}{l}\text { telah terjadi perubahan perilaku dan kesan terhadap } \\
\text { dirinya, dimana keberhasilan dalam peningkatan } \\
\text { kinerja mampu meningkatkan perasaan psikologis di } \\
\text { atas posisi sebelumnya. }\end{array}$ \\
\hline Tahap ketujuh & $\begin{array}{l}\text { telah berhasil dalam memberdayakan dirinya, merasa } \\
\text { tertantang untuk mendapatkan hasil yang lebih baik }\end{array}$ \\
\hline
\end{tabular}

Siklus pemberdayaan ini menggambarkan proses mengenai upaya individu dan komunitas untuk mengikuti perjalanan kearah prestasi dan kepuasan individu dan pekerjaan yang lebih tinggi. Proses bisa diartikan sebagai runtutan perubahan (peristiwa) dalam perkembangan sesuatu (Depdiknas, 2003), jadi proses pemberdayaan bisa dimaknai sebagai runtutan perubahan dalam perkembangan usaha untuk membuat masyarakat menjadi lebih berdaya. Wilson (1996) memaparkan empat tahapan dalam proses pemberdayaan sebagai berikut:

- Awakening atau penyadaran, pada tahap ini masyarakat disadarkan akan kemampuan, sikap dan keterampilan yang dimiliki serta rencana dan harapan akan kondisi mereka yang lebih baik dan efektif.

- Understanding atau pemahaman, lebih jauh dari tahapan penyadaran masyarakat diberikan pemahaman dan persepsi baru mengenai diri mereka sendiri, aspirasi mereka dan keadaan umum lainnya. Proses pemahaman ini meliputi proses belajar untuk secara utuh menghargai pemberdayaan dan tentang apa yang dituntut dari mereka oleh komunitas.

- Harnessing atau memanfaatkan, setelah masyarakat sadar dan mengerti mengenai pemberdayaan, saatnya mereka memutus-kan untuk menggunakannya bagi kepentingan komunitasnya.

- Using atau menggunakan keterampilan dan kemampuan pemberdayaan sebagai bagian dari kehidupan sehari-hari.

Pemberdayaan adalah sebuah proses, sehingga tidak bisa dipahami sebagai proyek tunggal dengan awal dan akhir. Suatu cara atau filosofi dimana pelaksanaan dan penyesuaiannya memerlukan pembinaan dan proses yang cukup lama (Wilson, 1996). 


\section{Lingkup dan Tingkatan Pemberdayaan.}

Agar kita dapat melakukan analisis dan pemahaman yang tepat mengenai pemberdayaan, harus dipahami dulu kerangka konseptual mengenai lingkup dan tingkatan pemberdayaan. Dari kajian-kajian empiris pelaksanaan pemberdayaan di masyarakat, Alshop dan Heinshon (2005) menggambarkan 3 hal dalam lingkup pemberdayaan, yaitu pemberdayaan politik, pemberdayaan ekonomi dan pemberdayaan sosial, sedangkan Ndraha (dalam Sumaryadi, 2005) menyebutkan satu lingkup lainnya pemberdayaan lingkungan.

Pemberdayaan politik lebih mengarah kepada upaya menyadarkan masyarakat untuk berpar- tisipasi dalam politik dan meningkatkan posisi tawar masyarakat terhadap pemerintah atau pihak-pihak lainnya, dalam aspek-aspek penegakan keadilan, kepemimpinan politik, dan pelayanan publik. Pemberdayaan ekonomi adalah pendekatan yang diutamakan kepada masyarakat kelas bawah untuk mampu beraktifitas dalam bidang ekonomi dan berpenghasilan yang lebih baik, sehingga mampu menanggung ekses pertumbuhan yang terjadi. Pemberdayaan sosial lebih merupakan upaya untuk meningkatkan kemampuan sumber daya manusia dan menyadarkan posisi dan peran seseorang dalam kaitannya dengan kehidupan sosial dalam komunitasnya. Sementara permberdayaan lingkungan adalah upaya yang untuk menjaga kelestarian lingkungan dan menjalin hubungan baik dalam interaksi manusia dengan lingkungannya.

Tingkatan pemberdayaan adalah semacam batasan luasan wilayah dalam proses pemberdayaan. Alshop dan Heinshon (2005) serta Fujikake (2008) menjabarkan tingkatan pemberdayaan menjadi tiga tingkatan yaitu local level, intermediary level, dan macro level.

Maksud dari tingkatan micro atau lokal yaitu dalam batasan wilayah lingkungan sekitar masyarakat tersebut atau pada tataran desa atau sekitar tempat tinggal. Tingkatan meso atau intermediary meliputi wilayah kota, jaringan atau hubungan antar organisasi dan pihak eksternal lain. Tingkatan macro adalah tingkatan yang lebih luas dari tingkatan-tingkatan sebelumnya, yaitu setingkat pengambilan keputusan dalam lingkup nasional.

\section{Pengembangan Kapasitas}

\section{a. Pengembangan Masyarakat .}

Dalampengembangankapasitasdisuatukomunitasmasyarakat, harus disadari bahwa mereka memiliki karakteristik budaya, geografi, sosial, politik, dan demografi yang unik, sehingga pengalaman pengembangan kapasitas di suatu komunitas masyarakat belum tentu dapat berjalan di 
masyarakat yang lain bahkan sangat beresiko mengalami kegagalan dan melemahkan pengalaman orang-orang dari masyarakat tersebut karena hal itu bukan proses yang cocok untuk mereka (Ife dan Tesoriero, 2008: 342). Peningkatan kapasitas kelemba-gaan berarti usaha meningkatkan peran dan mengembangkan tata kelembagaan di tingkat masyarakat sehingga mampu mewadahi setiap gagasan, usulan dan aspirasi dari masyarakat untuk kemajuan dalam komunitasnya. Outcome dari usaha ini adalah terbentuknya lembaga-lembaga berbasis komunitas untuk pembangunan dalam lingkungannya.

Peningkatan kapasitas juga meliputi usaha untuk meningkatkan kemampuan manajerial dan berorganisasi masyarakat dalam upaya mewujudkan tata kelembagaan yang partisipatif dan transparan.

\section{b. Elemen-elemen dalam Pengembangan Kapasitas.}

Elemen-elemen dalam pengembangan kapasitas merupakan hal-hal yang harus dilaksanakan dalam mencapai kondisi kapasitas masyarakat yang berkembang. Garlick dalam McGinty (2003) menyebutkan lima elemen utama dalam pengembangan kapasitas sebagai berikut:

a. Membangun pengetahuan, meliputi pening-katan keterampilan, mewadahi penelitian dan pengembangan, dan bantuan belajar

b. Kepemimpinan

c. Membangun jaringan, meliputi usaha untuk membentuk kerjasama dan aliansi

d. Menghargai komunitas dan mengajak komu-nitas untuk bersamasama mencapai tujuan

e. Dukungan informasi, meliputi kapasitas untuk mengumpulkan, mengakses dan mengelola informasi yang bermanfaat

\section{Evaluasi Pemberdayaan.}

Evaluasi pemberdayaan didefinisikan sebagai pendekatan evaluasi yang mengarah pada upaya meningkatkan kemungkinan pencapaian keberhasian program pemberdayaan yang lebih baik (Wandersman dalam Fetterman, 2007). Fetterman (2007) juga menjelaskan bahwa evaluasi pemberdayaan adalah merupakan proses untuk mendapatkan gambaran diri melalui evaluasi dan refleksi diri dalam tataran individu ataupun grup guna meningkatkan kualitas dirinya melalui inisiatifnya sendiri.

Terdapat beberapa pendekatan dan model evaluasi pemberdayaan. Guijt (2000) dan Rietbergen-McCracken (1998) menjelaskan bahwa evaluasi pemberdayaan harus dilakukan sendiri oleh masyarakat melalui rangkaian kegiatan partisipatif (participatory monitoring \& evaluation/PM\&E). Evaluasi partisipatif berbeda dengan pendekatan evaluasi konvensional 
(Riebergen- McCracken, 1998), dimana pendekatan evaluasi tradisional cenderung bersifat linear dan lebih berfungsi untuk menilai akuntabilitas manajemen dan keuangan sedangkan evaluasi partisipatif lebih bersifat open-ended dan iterative (berulang) dan lebih berfungsi untuk menjawab kebutuhan terhadap perubahan dalam kegiatan. Kritik Cousins (2005) terhadap teori evaluasi pemberdayaan Fetterman, bahwa tindakan evaluasi bisa dilihat dari dua sisi, yaitu evaluasi yang dilakukan oleh praktisi evaluasi atau bersifat praktis dan evaluasi yang dilakukan oleh peneliti/teorist. Oleh karena itu penelitian ini berusaha untuk menggunakan pendekatanpendekatan dan prinsip-prinsip evaluasi partisipatif namun dilakukan oleh peneliti di luar komunitas itu sendiri.

\section{a. Prinsip Evaluasi Pemberdayaan dan Pengembangan Kapasitas.}

Konsep evaluasi pemberdayaan yang dikemukakan Fetterman dan Wandersman (2007) lebih mengarah pada evaluasi faktor-faktor eksplisit daripada yang bersifat implisit. Fetterman menyampaikan 10 prinsipprinsip dalam evaluasi pemberdayaan adalah sebagai berikut:

- Improvement (peningkatan)

- Community ownership (kepemilikan komunitas)

- Inclusion (inklusi)

- Democratic participation partisipasi demokrasi)

- Social justice (keadian sosial)

- Community knowledge (tingkat pengetahuan komunitas)

- Evidence-based strategies (strategi berbasis alasan)

- Capacity building (pengembangan kapasitas)

- Organizational learning (Pembelajaran organisasi)

- Accountability (akuntabilitas)

Prinsip-prinsip evaluasi tersebut di atas merupakan panduan untuk melakukan evaluasi per-bagian dari proses pemberdayaan, baik secara konseptual maupun dalam implementasinya. Untuk meneliti atau mengevaluasi kinerja pengembangan kapasitas dalam proses pemberdayaan masyarakat, UNDP (2008) memaparkan kerangka kerja/ framework yang merupakan dimensi penilaian yang terdiri dari masukan (points of entry), yang berdasarkan tingkatannya (pengembangan kapasitas dalam level sistem, kelembagaan dan individu), isu utama (core issues), yang merupakan domain/ranah dalam pengembangan kapasitas yang terdiri dari penataan kelembagaan (institutional arrangement), kepemimpinan (leadership), pengetahuan (knowledge), dan akuntabilitas (accountability). Empat ranah dalam pengembangan kapasitas tersebut 
merupakan acuan tetapi bisa dikembangkan lebih lanjut disesuaikan berdasarkan kebutuhan dan situasi yang dihadapi. Dimensi ketiga dalam framework pengembangan kapasitas yaitu kapasitas fungsional/teknis. Kerangka kerja/ framework dalam evaluasi pengembangan kapasitas tersebut, dapat kita gunakan sebagai acuan dalam mengevaluasi capaian kegiatan pengembangan kapasitas masyarakat dengan melihatnya dari sisi outcome atau hasil.

\section{b. Model Evaluasi Pemberdayaan Fujikake.}

Model evaluasi pemberdayaan adalah salah satu bentuk alat analisis yang bisa digunakan untuk mengukur derajat keberdayaan suatu masyarakat. Pendekatan analisis yang digunakan oleh Fujikake (2008) dalam mengevaluasi pemberdayaan adalah dengan menggunakan pendekatan kualitatif, yaitu mencoba memahami hubungan antara tanggapan masyarakat dengan tujuan pemberdayaan itu sendiri untuk kemudian dituangkan dalam gambar-gambar dan skema-skema konsep tertentu. Model Fujikake ini telah dipraktikkan dalam mengevaluasi pemberdayaan perempuan di sebuah desa di Paraguay Fujikake (2008) dengan mengembangkan empat langkah dalam mengevaluasi pemberdayaan. Tahap pertama adalah melihat perubahan masyarakat dari tingkat kesadarannya. Hasil dari analisis mengenai perubahan tingkat kesadaran ini dituangkan dalam grafik yang menggambarkan tingkat perubahan kesadaran yang diklasifikasikan menjadi 3 yaitu "sangat baik", "telah berubah", dan "tidak seperti sebelumnya".

\section{METODE PENELITIAN.}

Penelitian ini dilakukan di Desa Sastrodirjan Kecamatan Wonopringgo Kabupaten Pekalongan, dimana program PNPM Mandiri yang diselenggarakan di desa ini dinilai cukup berhasil dalam memberdayakan masyarakat berbasis pengembangan kapasitas masyarakat. Populasi dari penelitian ini adalah masyarakat Desa Sastrodirjan, dan sampel yang dipilih adalah masyarakat yang terlibat atau pernah terlibat atau mengikuti agenda pengembangan kapasitas dalam kegiatan PNPM Mandiri Perkotaan.

Sedangkan jumlah sampel untuk kegiatan wawancara adalah menyesuaikan kondisi di lapangan, karena tujuan wawancara yang dilakukan adalah untuk mendapatkan data-data yang bersifat kualitatif, sehingga wawancara dapat dianggap cukup apabila telah didapatkan data yang mampu menjawab pertanyaan penelitian yang dikemukakan. Sampel ditentukan berdasarkan kriteria yang dipilih antara lain ketua dan pengurus Badan Keswadayaan Masyarakat (BKM) beserta unit pelaksananya, ketua dan pengurus Kelompok Swadaya Masyarakat (KSM), para relawan kegiatan PNPM Mandiri Perkotaan, Anggota dan tokoh masyarakat yang pernah terlibat dalam kegiatan-kegiatan PNPM Mandiri Perkotaan, fasilitator pendamping dan unsur aparat pemerintahan desa setempat. 


\section{HASIL DAN PEMBAHASAN.}

Di dalam analisis dan pembahasan ini dilakukan kajian untuk menjawab pertanyaan penelitian yang diajukan yaitu bagaimana pencapaian derajat keberdayaan masyarakat ditinjau dari proses pengembangan kapasitas masyarakat pada kegiatan PNPM-Mandiri Perkotaan di Desa Sastrodirjan berdasarkan data-data yang didapatkan selama penelitian dan kajian secara teoritis.

\section{Analisis Pelaksanaan Pengembangan Kapasitas.}

\section{a. Sosialisasi Program Pemberdayaan.}

Rangkaian kegiatan sosialisasi di tingkat masyarakat dilaksanakan selama lima bulan yang terdiri dari kegiatan sosialisasi awal, rembug kesiapan masyarakat, dan sosialisasi lanjutan pada bulan Maret sampai dengan Juli 2007. Sosialisasi awal oleh fasilitator pendamping dilaksanakan di tingkat kelurahan dan di tingkat masyarakat basis (RT, RW, kelompok masyarakat tertentu), antara lain pertemuan rutin $\mathrm{RT}$, pengajian tingkat RT, pengajian ibu-ibu, pertemuan PKK, dan pertemuan-pertemuan masyarakat lainnya.

Sosialisasi awal program ini mendapatkan tanggapan yang cukup baik dari masyarakat, karena masyarakat merasa senang akan mendapatkan bantuan dari pemerintah yang pengelolaan dan pelaksanaannya akan dilakukan sendiri oleh masyarakat.

Rangkaian kegiatan sosialisasi berikutnya adalah Rembug Kesiapan Masyarakat (RKM), yang intinya adalah menghimpun pernyataan masyarakat untuk memutuskan menerima atau menolak program pemberdayaan masyarakat PNPM Mandiri Perkotaan. Hasil rembug kesiapan masyarakat di Desa Sastrodirjan memutuskan untuk menerima PNPM dan menyatakan siap mengikuti siklus pemberdayaan yang dipersyaratkan oleh program. Sikap menerima program ini disamping dipengaruhi oleh keinginan masyarakat untuk berubah dari kondisi semula menjadi lebih baik, juga dipengaruhi oleh besaran dana bantuan langsung masyarakat yang akan diterima.

Sosialisasi lanjutan adalah memberikan pemahaman yang lebih mendalam kepada masyarakat tentang prinsip-prinsip pembangunan berbasis masyarakat dan upaya-upaya penanggulangan kemiskinan melalui siklus-siklus pemberdayaan yang telah dirancang dalam PNPM Mandiri Perkotaan. Kepala Desa selaku pimpinan pemerintahan di tingkat desa juga mendukung dilaksanakannya PNPM Mandiri Perkotaan di Desa Sastrodirjan, karena konsep pembangunan yang akan dilaksanakan adalah berupa pemberdayaan masyarakat melalui pembelajaran bersama seluruh komponen masyarakat. 


\section{b. Pelaksanaan Siklus Pemberdayaan PNPM.}

\section{- Refleksi Kemiskinan}

Kegiatan awal dalam siklus pemberdayaan PNPM Mandiri Perkotaan adalah refleksi kemiskinan. Refleksi kemiskinan ini dilakukan untuk menumbuhkan kesadaran kritis masyarakat terhadap akar penyebab masalah kemiskinan. Kegiatan refleksi kemiskinan ini dilaksanakan melalui Focus Group Discussion (FGD), yang dilaksanakan sebanyak 9 kali di tingkat basis masyarakat atau RT dan dalam pertemuan ibu-ibu PKK. Hasil dari refleksi kemiskinan di tingkat basis selanjutnya disampaikan dalam lokakarya refleksi kemiskinan tingkat desa yang diikuti oleh perwakilan dari tiap RT atau basis masyarakat untuk diambil kesepakatan bersama tentang kriteria masyarakat miskin di Desa Sastrodirjan. Indikator yang disepakati untuk mengidentifikasi kemiskinan adalah berdasarkan pekerjaan, pendapatan keluarga perbulan, pendidikan, dan kondisi rumah tinggal.

Ditinjau dari aspek pengembangan kapasitas, masyarakat bisa mendapatkan banyak pembelajaran dari kegiatan refleksi kemiskinan ini, mereka mendapatkan banyak cerita dan pengalaman mengenai agenda penanggulangan kemiskinan dari modul-modul yang disampaikan, serta dapat bertukar pikiran dengan fasilitator maupun sesama warga terutama dalam menyampaikan pandanganpandangannya mengenai kondisi kemiskinan dan kondisi sosial ekonomi lainnya.

\section{- Pemetaan Swadaya}

Rangkaian siklus pemberdayaan yang kedua adalah pemetaan swadaya (PS). Kegiatan Pemetaan Swadaya dilakukan untuk mendapatkan gambaran kondisi masyarakat, kondisi kemiskinan, potensi yang dimiliki masyarakat serta peluang, hambatan dan ancaman yang ada dalam mengatasi masalah-masalah kemiskinan dan masalah lingkungan di desanya.

Pelaksanaan pemetaan swadaya di Desa Sastrodirjan dilakukan oleh tim PS yang berjumlah 30 orang warga Desa Sastrodirjan yang terdiri dari 16 orang laki-laki (53\%) dan 14 orang perempuan (47\%). Hasil Pemetaan Swadaya adalah berupa data-data kondisi umum desa, permasalahan kemiskinan di tingkat desa, potensi yang dimiliki masyarakat serta profil dan karakteristik masyarakat miskin. Dari hasil pemetaan kemiskinan didapatkan tiga komponen daftar kebutuhan masyarakat Desa Sastrodirjan, yaitu komponen yang berkaitan dengan pembangunan sarana dan prasarana umum, komponen pembangunan usaha produktif, serta komponen rencana pengembangan kegiatan sosial dan peningkatan SDM. 
Komponen yang berkaitan dengan pembangunan sarana dan prasarana umum terdiri dari pembuatan/perbaikan saluran drainase, pengaspalan jalan, pavingisasi jalan, pembuatan bak sampah, perbaikan rumah. Komponen yang berkaitan dengan pembangunan usaha produktif yang terdiri dari bantuan modal usaha dan komponen yang berkaitan dengan rencana pengembangan kegiatan sosial dan peningkatan SDM berupa pembelian peralatan sewa alat pernikahan, pemberian santunan bagi warga miskin, jompo dan bantuan kesehatan, dan kursus-kursus keterampilan atau bantuan pendidikan.

Hasil pemetaan swadaya tahun 2007, mengidentifikasi ada sebanyak 123 KK miskin di Desa Sastrodirjan atau sejumlah 195 orang warga miskin (berdasarkan kriteria-kriteria yang telah disepakati sendiri oleh warga masyarakat, dan keikutsertaan sebagai penerima manfaat program sejenis sebelumnya (misalnya Raskin, BLT, Askeskin).

\section{- Pembangunan BKM}

Proses pembangunan BKM ini terdiri dari penyusunan Anggaran Dasar organisasi BKM, penyusunan panitia pembentukan BKM dan pemilihan anggota BKM. Penyusunan Anggaran Dasar (AD) organisasi BKM Desa Sastrodirjan dilakukan oleh masyarakat yang direpresentasikan oleh relawan dengan dipandu fasilitator. Pada tahap penyusunan AD ini peran fasilitator cukup besar, dengan memberikan contoh-contoh dokumen yang ada dan membantu secara langsung dalam proses penyusunannya, sehingga kemandirian masyarakat dalam penyusunan Anggaran Dasar ini masih kurang. Masyarakat sepakat untuk memberikan nama organisasi BKM dengan nama BKM "SADIR JAYA", yang mengandung maksud dan cita-cita agar dalam masa mendatang Desa Sastrodirjan lebih berjaya. Keberadaan BKM juga langsung didaftarkan pada notaris untuk mendapatkan status hukum yang tetap.

Kegiatan pembangunan BKM di Desa Sastrodirjan ini sebenarnya telah dimulai pada saat pemetaan swadaya, dimana masyarakat menentukan sendiri kriteria kepemimpinan yang diharapkan dengan basis nilai-nilai dan modal sosial sesuai hasil FGD kepemimpinan. Kriteria-kriteria pemimpin yang diinginkan tersebut yang selanjutnya disosialisasikan kepada masyarakat untuk memilih utusan-utusannya dalam pemilihan anggota BKM. Pemilu atau pemilihan utusan ditingkat RT dilaksanakan serentak di 7 RT tanpa kampanye dan propaganda apapun, yang berhasil memilih 34 orang utusan masyarakat untuk mengikuti pemilihan anggota BKM. Ke-34 orang utusan tersebut selanjutnya saling memilih dan dipilih untuk mendapatkan 9 orang anggota BKM berdasarkan perolehan suara terbanyak masing-masing utusan. Ditinjau dari aspek pengembangan kapasitas dalam proses 
pembangunan BKM ini, terdapat proses untuk mengembangkan aspek leadership, organization, political power, trust dan unity atau keselarasan.

\section{- Penyusunan PJM Pronangkis}

Perencanaan Jangka Menengah Program Penanggulangan Kemiskinan (PJM Pronangkis)

merupakan produk perencanaan jangka menengah (3 tahun) dilakukan di Desa Sastrodirjan sudah dilaksanakan menurut kaidah partisipatif, dimana terdapat 9 rangkaian kegiatan yang dilaksanakan yaitu sosialisasi ke warga tentang PJM Pronangkis, sosialisasi lanjutan dan pembentukan Tim PJM Pronangkis, bimbingan teknis PJM Pronangkis, lokakarya tingkat desa, penyusunan draft PJM Pronangkis, pertemuan untuk menyempurnakan PJM Pronangkis, sosialisasi dokumen dan bazar PJM Pronangkis.

Tim penyusun PJM Pronangkis Desa Sastrodirjan berjumlah 15 orang yang terdiri dari 11 orang laki-laki (73\%) dan 4 orang perempuan (27\%). Dilihat dari perspektif kesetaraan gender, maka keterwakilan perempuan sudah mencukupi, dimana dalam indikator keterwakilan perempuan yang disyaratkan oleh PNPM Mandiri Perkotaan 2007 adalah sebesar 20\%. Program-program yang tersusun dalam PJM Pronangkis Desa Sastrodirjan tahun 2008-2010 pun cukup banyak yang mengakomodir kepentingan perempuan, misalnya program penurunan angka kematian ibu hamil, penyuluhan $\mathrm{KB}$, pemberian makanan tambahan bagi ibu hamil dan balita.

\section{- Sinergi dengan Perencanaan Daerah.}

Implementasi pensinergian PJM Pronangkis Desa Sastrodirjan dengan perencanaan daerah dilaksanakan dalam bentuk penyelenggaraan Bazar PJM tingkat kecamatan yang dilaksanakan bersama-sama antara BKM se-Kecamatan Wonopringgo, pihak Pemerintah Kecamatan, Bappeda, Dinas, dan instansi-instansi terkait lainnya. Dalam kegiatan bazar tersebut masing-masing BKM mensosialisasikan program-programnya serta menawarkan potensi-potensi di daerahnya sehingga dapat diketahui oleh pihakpihak eksternal termasuk Pemerintah Kecamatan dan Kabupaten. Implementasi lain dari sinergi program penanggulangan kemiskinan dengan perencanaan daerah adalah dengan dilaksanakannya Program Penanggulangan Kemiskinan Terpadu (PAKET) yang dilaksanakan oleh panitia kemitraan yang terdiri dari BKM, masyarakat, Pemerintah Desa dan Pemerintah Kabupaten, yang diimplementasikan dalam bentuk kegiatan pengaspalan jalan Desa Sastrodirjan.

Aspek pengembangan kapasitas yang didapatkan masyarakat adalah meningkatnya akses terhadap informasi terutama dari pihak- 
pihak eksternal, meningkatnya jaringan kerja (networking) sehingga dengan jaringan yang tercipta masyarakat bisa mengoptimalkan potensi dan sumber daya yang ada serta dapat meminimalkan halangan-halangan yang selama ini dihadapi. Aspek pengembangan kapasitas yang lain adalah meningkatnya political power sehingga masyarakat melalui BKM memiliki nilai tawar yang lebih tinggi dalam pengambilan keputusan dan merencanakan pembangunan di daerahnya.

\section{- Pelaksanaan dan Pemantauan.}

Untuk melaksanakan kegiatan PNPM di Desa Sastrodirjan dari tahun 2007 sampai 2009 telah terbentuk 27 KSM yang terdiri dari 14 KSM yang mengerjakan kegiatan pembangunan lingkungan, 1 KSM kegiatan sosial dan $12 \mathrm{KSM}$ simpan pinjam atau keuangan. Sesuai daftar Rencana Tahunan Pronangkis yang disusun, masing-masing KSM mengajukan usulan kegiatan dalam bentuk proposal kegiatan yang selanjutnya diverifikasi dan dilakukan penilaian serta prioritasi oleh BKM dibantu oleh Unit Pengelola (UP) sesuai kegiatan yang diusulkan. Setelah usulan kegiatan disetujui dan telah cukup tersedia dana, maka dilakukan pencairan dana dan kegiatan dilaksanakan. Selama pelaksanaan kegiatan, fungsi monitoring dilaksanakan oleh segenap anggota masyarakat, dan untuk kegiatan pembangunan lingkungan harus disertai papan informasi kegiatan sehingga semua elemen masyarakat dapat mengakses informasi mengenai kegiatan yang dilaksanakan. Setelah kegiatan selesai dilaksanakan, maka KSM harus menyampaikan laporan pertanggungjawaban kegiatan kepada BKM melalui UP, dan pada akhir tahun dilaksanakan audit kelembagaan dan keuangan terhadap BKM yang dilaksanakan oleh lembaga auditor independen, dimana untuk pelaksanaan PNPM Mandiri Perkotaan di Kabupaten Pekalongan kegiatan auditing dilaksanakan oleh tim auditor dari Universitas Dian Nuswantoro Semarang dan STIE Muhammadiyah Pekalongan.

\section{- Review PJM Pronangkis .}

Kegiatan review partisipatif di Desa Sastrodirjan telah dilakukan dua kali, yaitu pada tahun 2008 untuk mengevaluasi kegiatan tahun 2008 dan merencanakan kegatan tahun 2009 serta review tahun 2009 untuk mengevaluasi kegiatan 2009 dan merencanakan kegiatan tahun 2010. Review dilaksanakan oleh panitia review partisipatif yang terdiri dari tim review kelembagaan, tim review program, dan tim review keuangan serta tim perumus.

Secara umum pelaksanaan siklus pemberdayaan masyarakat di Desa Sastrodirjan telah sesuai dengan ketentuan dan arahan dalam Program PNPM Mandiri Perkotaan serta sesuai dengan teori siklus 
pemberdayaan yang dikemukakan oleh Wilson dalam Sumaryadi (2005). Dilihat dari kesadaran dan kemandirian masyarakat dalam melaksanakan siklus partisipatif sebagaimana yang telah diajarkan kepada mereka, maka bisa dikatakan masyarakat Desa Sastrodirjan telah mampu untuk melaksanakan siklus pemberdayaan secara mandiri, namun dikaitkan dengan kondisi dan dinamika di masyarakat yang mulai kritis terhadap setiap kebijakan yang diberlakukan terhadap mereka, maka keberadaan fasilitator pendamping masih sangat diperlukan untuk mengawal berjalannya proses pemberdayaan dan memberikan masukan apabila terdapat konflik atau masalah dalam pelaksanaan pemberdayaan tersebut.

\section{c. Pelatihan masyarakat/coaching}

Pelatihan di PNPM Mandiri Perkotaan, pada dasarnya adalah pelatihan motivasional yaitu pelatihan yang mendorong peserta untuk mempunyai paradigma dan sikap mental yang positif yang mendukung upaya-upaya penanggulangan kemiskinan. Pelatihan yang dilakukan dalam PNPM secara umum dapat dibedakan menjadi dua, yaitu yang terkait dengan siklus dan non siklus. Pelatihan yang terkait dengan siklus diantaranya coaching refleksi kemiskinan, pelatihan dasar relawan, coaching pemetaan swadaya, coaching penyusunan PJM Pronangkis, pelatihan pratugas $\mathrm{BKM}$, pelatihan $\mathrm{BKM}$, pelatihan dasar, pelatihan madya, pelatihan utama dan kegiatan-kegiatan pelatihan lain yang mendukung berjalannya siklus pemberdayaan. Sedangkan pelatihan yang tidak terkait langsung dengan siklus diantaranya pelatihan pembuatan media warga, pelatihan manajemen penang-gulangan bencana berbasis masyarakat, pelatihan pengembangan data dan informasi komunitas, pelatihan UPK, pelatihan UPS, pelatihan UPL, pelatihan Kades, dan pelatihan-pelatihan/OJT keterampilan teknis lainnya.

Dalam pelaksanaan PNPM Mandiri Perkotaan di Desa Sastrodirjan, hampir semua jenis pelatihan yang direncanakan sesuai kurikulum PNPM telah dilaksanakan, baik yang diselenggarakan dalam lingkup desa/komunitas atau digabung dengan desa lain dalam satu cluster pendampingan atau tingkat kecamatan. Desa Sastrodirjan yang telah memasuki tahun ketiga pelaksanaan PNPM Mandiri Perkotaan, maka telah masuk dalam kategori lokasi utama, dan pelatihan-pelatihan yang dilaksanakan pun disesuaikan dengan perkembangan yang ada.

\section{d. Tingkatan dalam Pelaksanaan Pengembangan Kapasitas}

Rangkaian kegiatan pengembangan kapasitas masyarakat yang telah dilaksanakan dalam PNPM Mandiri Perkotaan di Desa Sastrodirjan baik yang terkait langsung dengan siklus pemberdayaan maupun kegiatankegiatan non-siklus dapat diklasifikasikan menurut tingkatannya dalam pemberdayaan. Tingkatan yang dimaksud terdiri dari tingkatan mikro 
(pada level individu dan kumunitas), meso (pada level organisasi atau kelembagaan), dan makro (pada level kebijakan dan sistem). Berikut merupakan bentuk-bentuk kegiatan pengembangan kapasitas yang telah dilaksanakan berdasarkan tingkatannya.

Tabel.1

Bentuk Pengembangan Kapasitas Berdasarkan Tingkat Pemberdayaan

\begin{tabular}{|c|l|}
\hline Tingkat pemberdayaan & Bentuk pengembangan kapasitas \\
\hline $\begin{array}{c}\text { Mikro (individu \& } \\
\text { komunitas) }\end{array}$ & $\begin{array}{l}\text { - coaching refleksi kemiskinan } \\
\text { - pelatihan dasar relawan } \\
\text { - coaching pemetan swadaya } \\
\text { - pelatihan /OJT keterampilan teknis lainnya }\end{array}$ \\
\hline $\begin{array}{c}\text { Meso (kelembagaan \& } \\
\text { organisasi) }\end{array}$ & $\begin{array}{l}\text { - pelatihan BKM (pelatihan dasar, pelatihan } \\
\text { madya, pelatihan utama ) }\end{array}$ \\
& $\begin{array}{l}\text { - pelatihan UPK Pelatihan UPS pelatihan } \\
\text { UPL }\end{array}$ \\
\hline $\begin{array}{c}\text { Makro (kebijakan \& } \\
\text { sistem) }\end{array}$ & $\begin{array}{l}\text { - pelaching penyusunan PJM Pronangkis } \\
\text { - pelatihan pembuatan media warga majemen penanggulangan } \\
\text { bencana pelatihan pengembangan data } \\
\text { dan informasi komunitas Pelatihan BKM } \\
\text { - pelatihan dan lokakarya tematik kabupaten }\end{array}$ \\
\hline
\end{tabular}

Sumber : Analisis Penulis

\section{e. Pendekatan Peningkatan Kapasitas Masyarakat.}

Upaya dan pendekatan yang dilaksanakan dalam mengembangkan kapasitas masyarakat di Desa Sastrodirjan adalah melalui pendekatan sosio kultural masyarakat setempat, serta pendekatan keagamaan. Di Desa Sastrodirjan sosok kyai atau tokoh agama masih memiliki peran dan pengaruh yang cukup kuat dalam menggerakkan masyarakat. Pendekatan tersebut cukup efektif dalam menggerakkan dan mempengaruhi masyarakat, namun ditinjau dari sasaran pengembangan kapasitas masyarakat secara keseluruhan hal tersebut kurang tepat, karena apabila seorang tokoh masyarakat atau tokoh agama menyampaikan suatu pendapat maka warga yang lain cenderung untuk mengikutinya. Hal tersebut dikhawatirkan justru memunculkan 
pendekatan top down dalam skala komunitas atau lingkup yang lebih kecil. sehingga masyarakat kelas bawah atau masyarakat miskin sebagai kelompok sasaran utama program tidak punya cukup keberanian dalam mengemukakan aspirasinya.

Pendekatan yang lain adalah melalui pendekatan gender, selama ini peran kaum perempuan cenderung untuk berada di bawah kaum lakilaki, sehingga memerlukan pendekatan khusus agar kaum perempuan juga bisa berpartisipasi secara lebih luas dalam rangka pembangunan lingkungan pada khususnya dan penanggulangan kemiskinan pada umumnya. Pendekatan gender ini dapat terlihat dari rangkaian sosialisasi dan FGD yang dilaksanakan khusus bagi kaum perempuan yang diadakan bersamaan dengan agenda pertemuan ibu-ibu PKK. Kelemahan dari pendekatan ini adalah bahwa melalui forum-forum yang dilaksanakan khusus untuk perempuan mereka bisa menyampaikan aspirasinya secara lebih terbuka, namun karena kegiatan yang dilaksanakan merupakan kegiatan masyarakat secara kolektif maka bisa jadi aspirasi perempuan yang terhimpun kurang bisa diterima dalam forum kolektif yang banyak didominasi kaum laki-laki, karena dalam kehidupan dan sistem sosial-budaya masyarakat desa posisi kaum perempuan masih kalah dibandingkan dengan laki-laki.

Dilihat dari karakteristik sosial masyarakat Desa Sastrodirjan yang sebagian besar berprofesi sebagai petani dan buruh industri maupun buruh bangunan dimana waktu kerjanya adalah dari pagi sampai sore hari, maka bisa dikatakan bahwa masyarakat memiliki waktu luang yang lebih banyak untuk aktivitas sosial kemasyarakatan adalah pada malam hari, sehingga pertemuan-pertemuan yang dilaksanakan juga rata-rata diselenggarakan pada malam hari. Pertemuan-pertemuan yang diselenggarakan pada malam hari biasanya dilaksanakan sehabis Isya (penyebutan istilah waktu yang lebih sering dipakai dari pada penyebutan waktu dalam format jam) atau kira-kira pukul 19.30 WIB, meskipun dalam pelaksanaannya baru dimulai acara sekitar pukul 20.00 WIB atau 20.30 WIB. Pelaksanaan pertemuan pada malam hari memang membawa kondisi pertemuan masyarakat lebih santai dan akrab, namun dilihat dari durasi waktu, maka waktu yang tersedia pada pertemuan di malam hari cukup terbatas, apalagi dilaksanakan berbarengan dengan kegiatan keagamaan dan kegiatan lain, padahal materi-materi yang harus disampaikan kepada masyarakat cukup banyak sehingga banyak agenda-agenda yang menjadi terlewatkan. 


\section{Analisis Evaluasi Pemberdayaan.}

\section{a. Analisis Perubahan Kesadaran Masyarakat.}

Tingkat kesadaran masyarakat Desa Sastrodirjan terhadap masalah kemiskinan dan pembangunan di lingkungannya cukup tinggi. Kesadaran masyarakat untuk peduli terhadap anggota komunitasnya disamping didorong oleh serangkaian kegiatan pengembangan kapasitas yang selama ini dilaksanakan juga didukung oleh basis nilai-nilai agama yang melekat kuat dalam masyarakat Desa Sastrodirjan. Tingkat kepedulian masyarakat terhadap pelaksanaan program pemberdayaan juga terlihat dari tingkat kekritisan warga dalam menyampaikan usulan atau kritik terhadap program-program yang dijalankan. Meskipun apabila dilihat secara lebih dekat dapat diketahui bahwa warga yang kritis hanya personil itu-itu saja yang notabene merupakan kelompok elite warga yang antara lain terdiri dari tokoh agama, tokoh masyarakat, tokoh pemuda, perangkat desa, dan pegawai, namun adanya kelompok warga yang kritis bisa dijadikan sebagai pendorong dan pemacu serta sumber pembelajaran bagi anggota masyarakat yang lain untuk lebih peduli terhadap permasalahan dalam komunitasnya.

Tingkat kesadaran masyarakat untuk lebih mengutamakan kepentingan umum daripada kepentingan pribadi juga nampak dari program-program yang sifatnya general dan tidak hanya menguntungkan satu kelompok saja, hal ini dapat terlihat dari program pembangunan infrastruktur jalan berupa kegiatan pavingisasi dan pengaspalan yang lebih mengutamakan pemerataan untuk semua wilayah atau RT. Dilihat dari sasaran program hal ini kurang tepat karena sebenarnya kelompok sasaran utama dari kegiatan-kegiatan yang dilaksanakan seharusnya adalah masyarakat miskin dan kelompok rentan lainnya, sehingga prioritasi dalam menentukan kegiatan seharusnya mengacu pada kegiatan yang dampaknya dapat mengurangi tingkat kemiskinan masyarakat secara langsung.

Motivasi masyarakat untuk melakukan perubahan menuju kondisi yang lebih baik secara umum cukup tinggi, dimana masyarakat bersedia secara sukarela terlibat dan menjadi bagian dari program tanpa upah atau insentif apapun. Namun dilihat dari aspek kemandirian maka motivasi yang dimiliki masyarakat masih belum cukup kuat, hal ini dapat dilihat dari adanya keluhan terhadap berkurangnya peran fasilitator kelurahan pada tahun kedua. Sesuai dengan program dan kebijakan dari koordinator manajemen wilayah pada tahun 2009 terjadi pengurangan jumlah fasilitator sehingga intensitas pertemuan dan interaksi antara fasilitator dengan masyarakat berkurang yang menyebabkan intensitas masyarakat untuk mengelola program juga berkurang, sehingga bisa dikatakan masyarakat masih belum cukup mandiri dan masih 
memerlukan dukungan dari pihak lain untuk menjaga agar motivasi yang dimiliki masyarakat tidak padam atau hilang.

Tingkat kepuasan masyarakat terhadap hasil-hasil kegiatan yang dilaksanakan dalam PNPM MP cukup baik, disamping itu masyaakat juga menyatakan kepuasannya terhadap proses pelaksanaan pekerjaan yang dilaksanakan. Pendekatan partisipatif yang diterapkan dalam pelaksanaan kegiatan PNPM MP dirasakan dapat menumbuhkan kembali jiwa dan semangat gotong royong dalam masyarakat yang selama ini mulai berkurang sehingga disamping kepuasan terhadap hasil pembangunannya, juga proses selama pelaksanaan pembangunan tersebut.

\section{b Analisis Elemen-elemen Pemberdayaan.}

Elemen-elemen pemberdayaan yang dilaksanakan dalam kegiatan PNPM MP terdiri dari tiga hal yaitu pemberdayaan lingkungan, pemberdayaan sosial dan pemberdayaan ekonomi. Dalam analisis ini ditambahkan satu elemen lagi yang dapat dijadikan sebagai tolok ukur tingkat keberdayaan masyarakat yaitu pemberdayaan politik.

\section{- Pemberdayaan Lingkungan}

Kegiatan pembangunan lingkungan dalam PNPM MP ini diorganisir oleh Unit Pengelola Lingkungan (UPL) yang berada di bawah BKM. Pemberdayaan lingkungan sebagai salah satu komponen dalam pelaksanaan program pemberdayaan masyarakat PNPM Mandiri Perkotaan di Desa Sastrodirjan menunjukkan hasil yang cukup baik, hal ini bisa dilihat dari perencanaan pembangunan yang sudah terrinci dalam PJM Pronangkis dan Rencana Tahunan, pembentukan KSM sebagai pelaksana kegiatan, penghimpunan swadaya masyarakat, serta pelaksanaan dan monitoring kegiatan selama dan paska pembangunan. Pembangunan fisik lingkungan di Desa Sastrodirjan didukung kemudahan berupa keberadaan penambangan material bangunan berupa pasir dan batu kali yang lokasinya dekat serta keberadaan tenaga kerja yang jumlahnya cukup memadai, karena sebagian besar masyarakat memiliki keterampilan sebagai pekerja bangunan, sehingga potensi swadaya masyarakat berupa material dan tenaga kerja cukup besar. Namun potensi yang ada tersebut belum didukung upaya meningkatkan keterampilan dan kreativitas masyarakat, misalnya pelatihan teknik dan manajemen konstruksi sehingga kegiatan yang dilaksanakan dapat lebih efektif dan efisien. Program-program yang disusun dalam PJM Pronangkis sudah cukup sesuai dengan kebutuhan masyarakat, namun sebagian besar program pembangunan yang direncanakan masih mengandalkan dana Bantuan Langsung Masyarakat (BLM) yang bersumber dari 
pemerintah sebagai sumber pembiayaan utama, sehingga ditinjau dari tingkat kemandirian bisa dikatakan kemandirian masyarakat masih kurang.

\section{- Pemberdayaan Sosial.}

Pelaksanaan kegiatan pemberdayaan sosial dalam PNPM MP di Desa Sastrodirjan termasuk sangat kurang dimana dari rencanarencana kegiatan yang telah diprogramkan hampir semua belum terlaksana, karena dana kegiatan yang sedianya digunakan untuk kegiatan sosial dialihkan sementara untuk membantu penyediaan jaringan air bersih bagi masyarakat. Rencana-rencana kegiatan sosial yang disusun antara lain pelatihan kerajinan batu, pelatihan pembuatan besi kolom, penyewaan layos/alat-alat pesta pernikahan, khitanan massal, penyuluhan penanggulangan narkoba, penyuluhan kesehatan ibu hamil, penyuluhan KB, pengasapan (fogging) untuk pemberantasan penyakit demam berdarah, penyediaan pupuk untuk petani, pelayanan pengobatan gratis, pendirian program paket $\mathrm{B}$ dan $\mathrm{C}$, kursus komputer, beasiswa bagi anak kurang mampu, dan pendirian perpustakaan desa.

Dari keluaran proses perencanaan berupa program yang tersusun, pemberdayaan sosial di Desa Sastrodirjan cukup baik karena sebagian besar benar-benar merupakan kebutuhan masyarakat sebagaimana hasil pemetaan swadaya sebelumnya, namun dokumen perencanaan seharusnya memuat secara lebih detail skenario dan strategi pelaksanaannya. Strategi dan skenario yang dimaksud adalah sebagai panduan dalam melakukan prioritasi dan acuan dalam pelaksanaan program pemberdayaan sosial sehingga sasaran yang direncanakan benar-benar dapat tercapai.

Aspek pengembangan kapasitas lain dalam pemberdayaan sosial yang lebih utama adalah terprogram dan berkelanjutan dan dalam PNPM MP telah dikonsepkan terciptanya proses belajar bersama tersebut dalam satu wadah yaitu Komunitas Belajar Kelurahan (KBK). Melalui komunitas tersebut, masing-masing anggota masyarakat dapat saling belajar sesuai dengan kebutuhan dan minat masingmasing.

Kegiatan-kegiatan pelatihan yang sudah terlaksana dalam PNPM MP di Desa Sastrodirjan sebagian besar adalah kegiatan yang diprogramkan oleh fasilitator pendamping dan bersifat general serta dilaksanakan di semua desa/kelurahan, sedangkan kegiatan pembelajaran yang murni muncul dari inisiatif masyarakat belum ada, meskipun dari dokumen perencanaan dapat dilihat agenda-agenda pelatihan atau pembelajaran masyarakat cukup banyak. Dari hal tersebut dapat dikatakan bahwa komunitas belajar kelurahan (KBK) 
di Desa Sastrodirjan belum efektif dalam memberikan pembelajaran bagi semua anggota komunitasnya.

\section{- Pemberdayaan Ekonomi.}

Kegiatan pemberdayaan ekonomi yang dimaksud berupa pengelolaan dana pinjaman bergulir dan pembinaan usaha yang secara kelembagaan dikelola oleh unit pengelola keuangan (UPK) yang berada di bawah koordinasi BKM. Peminjaman dana bergulir harus dilakukan melalui mekanisme KSM (Kelompok Swadaya Masyarakat) atau kelompok kecil masyarakat yang terdiri dari 10 orang untuk mengajukan peminjaman dana secara berkelompok. Proposal pengajuan dana yang diajukan KSM baru dapat direalisasikan setelah dilakukan diverifikasi oleh UPK dan disetujui oleh BKM.

Kegiatan perguliran dana pinjaman di Desa Sastrodirjan termasuk dalam kategori yang bagus dimana dari hasil review keuangan yang dilaksanakan pada akhir tahun kedua (tahun 2009) menunjukkan kinerja yang sangat baik. Kejadian kredit macet (non performing loan) sangat kecil dan perolehan bunga pinjaman yang dikelola menunjukkan hasil yang cukup besar, dimana dari aset awal sebesar 60 juta rupiah dalam setengah tahun perguliran telah berhasil terkumpul bunga pinjaman sebesar 5 juta rupiah. Namun kondisi pengelolaan perguliran dana pinjaman di Desa Sastrodirjan yang cukup baik saat ini belum didukung oleh pembinaan usaha yang optimal. Masyarakat yang mengajukan pinjaman terbatas pada besaran dana pinjaman yaitu sebesar Rp. 500.000,- dan hampir semua anggota KSM meminjam sejumlah tersebut.

Dilihat dari aspek pengembangan kapasitas, maka bisa dikatakan kondisi masyarakat yang ada sekarang belum banyak mengalami peningkatan kemandirian dalam mendapatkan peluang untuk mendapatkan pekerjaan sehingga dapat meningkatkan tingkat kesejahteraannya. Sasaran dari pemberdayaan ekonomi ini sebenarnya adalah meningkatnya kapasitas masyarakat untuk mengakses peluang-peluang dan mengelola sumber daya perekonomian yang tersedia, melalui pemberian stimulus dan pembinaan usaha secara intensif dan berkelanjutan, maka masyarakat dapat dikatakan berdaya secara ekonomi ketika mereka mampu menjalankan roda perekonomian dalam komunitasnya secara baik, efektif dan efisien. Kondisi semacam itu belum nampak dalam komunitas masyarakat di Desa Sastrodirjan karena keberadaan stimulus dana yang ada belum dibarengi dengan pembinaan usaha secara terpadu.

\section{- Pemberdayaan Politik}

Pemberdayaan politik sebenarnya bukan merupakan salah satu 
komponen tersendiri dalam pemberdayaan masyarakat PNPM $\mathrm{MP}$, namun secara implisit hal ini merupakan salah satu elemen penting dalam memberdayakan masyarakat terutama dalam aspek pengembangan kapasitas. Ranah pemberdayaan politik yang dimaksud tidak ada kaitannya dengan upaya untuk melibatkan masyarakat dalam perpolitikan negara, terlibat dalam partai politik tertentu maupun politik yang berkaitan dengan kepemimpinan kepala daerah. Ranah pemberdayaan politik.

\section{KESIMPULAN.}

Berdasarkan hasil analisis baik secara kuantitatif maupun secara kualitatif serta pembahasan yang telah dilakukan dapat ditarik kesimpulan sebagai berikut :

1. Hakikat program pemberdayaan adalah pembelajaran bagi masyarakat, sehingga bisa dikatakan bahwa elemen utama dari pemberdayaan adalah pengembangan kapasitas masyarakat itu sendiri. Rangkaian pengembangan kapasitas dalam PNPM Mandiri Perkotaan yang terdiri dari kegiatan sosialisasi, pelaksanaan siklus, dan pelatihan di Desa Sastrodirjan telah dijalankan dengan baik, dengan menggunakan pendekatan sosio-kultural yaitu dengan memperhatikan aspek keagamaan, aspek gender dan kebiasaan sehari-hari masyarakat.

2. Evaluasi pemberdayaan masyarakat bisa dilakukan melalui kajian evaluatif terhadap proses maupun hasilnya. Temuan evaluatif terhadap proses pemberdayaan masyarakat di Desa Sastrodirjan menunjukkan bahwa proses pemberdayaan yang dilakukan telah sesuai dengan tahapan pemberdayaan yang tentukan dalam PNPM Mandiri Perkotaan maupun dengan literatur-literatur mengenai pemberdayaan masyarakat. Sedangkan temuan evaluatif terhadap hasil menunjukkan bahwa proses pemberdayaan yang telah berjalan selama 3 tahun telah berhasil mengubah tingkat kesadaran masyarakat dan meningkatkan pemahamannya untuk turut serta berperan dalam pembangunan di komunitasnya, namun untuk mencapai tingkat kemandirian dan derajat keberdayaan yang sesungguhnya masih diperlukan pembelajaran lebih lanjut yang harus dilakukan secara kontinyu dan terpadu.

3. Pemberdayaan masyarakat melalui pemberdayaan lingkungan, sosial dan ekonomi secara tidak langsung juga mendorong terlaksananya pemberdayaan politik, dimana melalui rangkaian pengembangan kapasitas, masyarakat bisa belajar banyak mengenai kelembagaan, kepemimpinan dan manajemen komunitas sehingga menjadikan mereka memiliki tanggungjawab yang lebih besar dalam pembangunan dan memiliki posisi tawar yang lebih besar dalam hubungannya dengan pihak lain di luar komunitasnya . 


\section{DAFTAR PUSTAKA}

Abraham, et al, 2005, The Principle of mpowerment Evaluation, Empowerment Evaluation: Principles in Practice, New York: The Gulford Press

Adams, Robert, 2003, Social Work and Empowerment, New York: Palgrave Macmillan

Adi, Isbandi Rukminto, 2008, Intervensi komunitas Pengembangan Masyarakat sebagai Upaya Pemberdayaan Masyarakat, Jakarta: Rajawali Pers

Adler, Patricia A dan Adler, Peter, 2009, Teknik-teknik Observasi, Handbook of Qualitative Research, Yogyakarta: Penerbit Pustaka Pelajar

Bartle, Phil, 2007, Elements of Community Strength, http://www.scn.org / $\mathrm{mpfc} / \mathrm{modules} / \mathrm{mea}-\mathrm{elin} . \mathrm{htm} \#$ Measuring, diunduh pada 4 Nopember 2009.

BPS \& Bappeda Kabupaten Pekalongan. 2008. Kabupaten Pekalongan Dalam Angka 2007, Kajen : BPS \& Bappeda Kabupaten Pekalongan.

BPS \& Bappeda Kabupaten Pekalongan. 2008. Kecamatan Wonopringgo Dalam Angka 2007, Kajen : BPS \& Bappeda Kabupaten Pekalongan.

Cousins, J. Bradley, 2005, Will The Real Empowerment Evaluation Please Stand Up: A Critical Friend Perspective, Empowerment Evaluation: Principles in Practice, New York: The Gulford Press

Depdiknas, 2003, Kamus Besar Bahasa Indonesia, Edisi Ketiga, Jakarta: Penerbit Balai Pustaka

Departemen Pekerjaan Umum, 2008a, Pedoman Operasional Umum PNPM Mandiri Perkotaan 2008

Departemen Pekerjaan Umum, 2008b, Review Partisipatif: Modul Khusus Fasilitator (F24) Pelatihan Madya I

Fetterman, David and Wandersman, Abraham, 2007, Empowerment Evaluation: Yesterday, Today, and Tomorrow, American Journal of Evaluation 2007; 28; 179

Fontana, Andrea dan Frey, James H, 2009, Wawancara Seni Ilmu Pengetahuan, Handbook of Qualitative Research, Yogyakarta: Penerbit Pustaka Pelajar

Foy, Nancy, 1994, Empowering People at Work, London:Grower Publishing Company

Fujikake, Yoko, 2008, Qualitative Evaluation: Evaluating People's Empowerent, Japanese Journal of Evaluation Studies, Vol 8 No 2, 2008, pp 25 - 37, Japan Evaluation Society 
Guijt, Irene, 2000, Methodological Issues in Participation Monitoring and Evaluation, Learning From Change Issues and Experiences in Participatory Monitoring and Evaluation, Canada: ITDG Publishing.

Gulo, W, 2002, Metodologi Penelitian, Jakarta: Penerbit PT Grasindo

Huberman, A Michael dan Miles, Mattew B, 2009, Manajemen Data dan Metode Analisis, Handbook of Qualitative Research, Yogyakarta: Penerbit Pustaka Pelajar

Ife, Jim dan Tesoriero, Frank, 2008, Community Development: Alternatif Pengembangan Masyarakat di Era Globalisasi, Yogyakarta: Penerbit Pustaka Pelajar

James, Valentine Udoh, 1998, Capacity Building in Developing Countries: Human and nvironmental Dimensions, London: Praeger Publishers

Koentjaraningrat, 2000, Pengantar Ilmu Antropologi, cetakan kedelapan, Jakarta : Penerbit Rineka Cipta

Lichfield, Nathaniel, 2005, Community Impact Evaluation, London: UCL Press

Mayo, Marjorie, 2000, Cultures, Communities, Identities: cultural strategies for participation and empowerment, New York: Palgrave Macmillan

McGinty, Sue, 2003, The literature and theories behind community capacity building, In: Sharing Success: an Indigenous perspective. VIC, Australia:Common Ground Publishing, pp. 65-93.

Miles, Matthew B. dan Huberman, A. Michael, 1992, Analisis Data Kualitatif, Jakarta: Penerbit Universitas Indonesia

Miller, Delbert C, 1977, Handbook of Research Design and Social Measurement, New York: Longman Inc.

Kerlinger, Fred N, 2006, Asas-asas penelitian behavioral, Yogyakarta: Gajahmada University Press

Patton,Carl V dan Sawicki, David S, 1986, Basic Methods of Policy Analysis and Planning, New Jersey: Prentice Hall

Patton, Michael Quinn, 2009, Metode Evaluasi Kualitatif(How to Use Qualitative Methods in Evaluation), Yogyakarta: Penerbit Pustaka Pelajar

Potts, David dkk, 2003, Development Planning and Poverty Reduction, New York: Palgrave Macmillan

Riduwan, 2009, Metode E Teknik Menyusun Tesis, Bandung: Penerbit Alfabeta

Rietbergen-McCracken, Jennifer, dan Narayan, Deepa, 1998, Participation and Social Assessment: Tools and Techniques,Washington D.C.: The International Bank for Reconstruction and Development/The World Bank 
Salim, Agus, 2001, Teori dan Paradigma Penelitian Sosial, Yogyakarta: Penerbit PT Tiara Wacana

Soekanto, Soerjono, 2003, Sosiologi; Suatu Pengantar, Penerbit Jakarta : PT RajaGrafindo Persada

Soetomo, 2006, Strategi-strategi Pembangunan Masyarakat, Yogyakarta: Penerbit Pustaka Pelajar

Sugiyono, 2009, Metode Penelitian Kuantitatif, Kualitatif dan RED, Bandung: Penerbit Alfabeta

Sumaryadi, I Nyoman, 2005, Perencanaan Pembangunan Daerah Otonom dan Pemberdayaan Masyarakat, Jakarta: Penerbit Citra Utama

Ubaedillah, A. dan Rozak, Abdul, 2008, Pendidikan Kewargaan Demokrasi, Hak Asasi Manusia dan Masyarakat Madani, Jakarta: Kencana Prenada Media Group

Ukaga, Okechukwu and Maser, Chris, 2004, Evaluating Sustainable Development: Giving People A Voice In Their Destiny, Virginia: Stylus Publishing

UNDP, 2002, Handbook on Monitoring and Evaluating for Result, New York: United Nation Development Programme

UNDP, 2008, Capacity Development Practice Notes, New York: United Nation Development Programme

UNDP, 2009, Capacity Development: A UNDP Primer, New York: United Nation Development Programme

UNDP, 2010, Capacity is Development: Stories of Institution, New York: United Nation Development Programme Wandersman.

Wilson, Terry, 1996, The Empowerment Mannual, London: Grower Publishing Co 